\title{
The ultimate goal of curative anti-cancer therapies: inducing an adaptive anti-tumor immune response
}

\section{Wolf H. Fridman 1,2,3*, Jean-Luc Teillaud 1,2, Catherine Sautès-Fridman 1,2, Franck Pagès, , Jérôme Galon ${ }^{1,2,3}$, Jessica Zucman-Rossi ${ }^{2,3,4}$, Eric Tartour ${ }^{2,3,4,5}$, Laurence Zitvogel $6,7,8$ and Guido Kroemer 1,2,3,9,10,11}

INSERM U872, Centre de Recherche des Cordeliers, Paris, France

2 Université Paris-Descartes, Paris, France

3 Hôpital Européen Georges Pompidou, Assistance Publique Hopitaux de Paris, Paris, France

4 INSERM U674, Paris, France

5 INSERM U970, Paris-Cardiovascular Research Cente, Paris, France

${ }_{6}^{6}$ Institut Gustave Roussy, Villejuif, France

CBT 507, Centre of Clinical Investigations, Villejuif, France

${ }^{8}$ Université Paris Sud, Villejuif, France

9 INSERM U105, Villejuif, France

10 INSERM U848, Villejuif, France

"Metabolomics Platform, Institut Gustave Roussy, Villejuif, France

*Correspondence: herve.fridman@crc.jussieu.fr

Despite a century of intensive biological and pharmacological research resulting in hundreds of new drugs and clinical trials, the only curative therapy of most solid tumors remains surgery of localized disease. Once metastatic cells have left primary tumors and have hidden in protective niches or nidated in distant organs, patients will eventually experience recurrence and finally death. Physical agents used in radiotherapy may delay regional spreading whereas chemical agents used in chemotherapies may induce tumor shrinking but rarely totally eradicate cancers at a systemic stage. In addition, these effects are obtained at the price of intense toxicity which hampers the treatment of older patients, at an age when most cancers occur. Targeted therapies, interfering with pathways critical for the cancer cells, which have proven efficacy in hematological malignancies, are still in their infancy for solid tumors and it becomes now evident that cancer cells are capable to develop escape mechanisms to this new class of drugs.

Immunotherapies have been for a long time a matter of hopes and disillusions. In the recent years, however, they have begun to gain their place among the therapeutic arsenal of cancer therapies. They are classically thought to work through two mechanisms, the first the direct destruction of tumor cells, the second indirect anti-cancer effects via stimulation of the immune system. The destruction of tumor cells can be achieved by monoclonal antibodies which recruit effector NK cells and macrophages and possibly neutrophils to the tumor through their Fc portion, and trigger their $\mathrm{Fc}$ receptors resulting in killing of the malignant cells (Clynes et al., 1998; Carter, 2006). Several monoclonal antibodies of this type have been approved including rituximab (an anti-CD20 antibody) for B cell malignancies, cetuximab (an anti-EGF receptor antibody) for wild-type Ki-Ras colorectal cancer, or trastuzumab (an antiHER2/neu antibody) for breast and head and neck cancers (Galluzzi et al., in press). A direct destruction of tumor cells can also be achieved by cellular therapies such as the infusion of allogeneic hematologic stem cells, from bone marrow or blood, approved for the treatment of leukemia (Ashfaq et al., 2010) or that of differentiated cytotoxic $\mathrm{T}$ cells for the treatment of solid tumors, although the latter are still in clinical trials (Rosenberg et al., 2011). The other approach, immunostimulation of the immune system has been historically achieved by bacteria or bacterial extracts (e.g., the Coley toxin). BCG is still used to treat superficial bladder cancer (Finn, 2008; Disis, 2010). The modern version of this approach of non-specific stimulation is represented by interleukin 2 , which is approved for the treatment of metastatic melanoma and renal cancer (Rosenberg et al., 1987). Therapeutic vaccines have become a reality with the approval of Provenge as a treatment for metastatic, hormone refractory prostate cancer with autologous dendritic cells (DC) pulsed with a prostatic antigen, PSMA fused to GM-CSF (Beer et al., 2011; Gulley and Drake, 2011). PROSTVAC, a therapeutic vaccine for the same disease which uses poxvirus as a vector and PSA as an antigen, is in advanced stage of clinical validation (Kantoff et al., 2010). The most promising agents are, again, monoclonal antibodies that modulate the immune system. Ipilimumab, an anti-CTLA- 4 antibody which blocks CTLA-4/CD28 interaction and therefore unlocks a lymphocyte checkpoint, has recently been approved for the treatment of metastatic melanoma (Hodi et al., 2010). Anti-PD1 antibodies which unlock the PD1/PDL-1 checkpoint are being explored in phase II studies (Waldmann, 2006; Kline and Gajewski, 2010; Rosenblatt et al., 2011). Bevacizumab (Yang et al., 2003), an antibody which neutralizes VEGF, approved for the treatment of colorectal, lung and breast cancers, has a dual effect: it decreases the neo-vascularization of tumors but it also blocks the maturation-inhibiting activity of VEGF on DC, resulting in a decrease in regulatory $\mathrm{T}$ cells and myeloïd derived suppressor cells, and thus acts as an immunomodulatory agent (Tartour et al., 2011).

The last decade witnessed the development of these new therapies but also the achievement of comprehensive analyses of the immune microenvironment of human tumors that shed light on what components of the local immune infiltrate influence cancer development and how they impact various parameters of patients clinical outcome. The deepest studies were performed in colorectal cancers (Galon et al., 2006; Pagès et al., 2010; Fridman et al., 2011a,b; Mlecnik et al., 2011; Tosolini et al., 2011) and most of the conclusions reached in these 
analyses were reported to apply to many other tumors, such as ovarian, lung, breast, head and neck, prostate, liver, urothelial carcinoma, or melanoma (Fridman et al., 2011b). The main finding was that infiltration of primary tumors by high numbers of memory Th1/cytotoxic $\mathrm{T}$ cells both in the core ("center") and the invasive margin of the tumor nests was associated with good clinical outcome (Galon et al., 2006). Pro-inflammatory cells (Th-17; Tosolini et al., 2011) or cytokines (IL-17, IL-6, etc.; Tartour et al., 1996; Tosolini et al., 2011) are associated with poor prognosis. The case of regulatory $\mathrm{T}$ cells is more complex: they are associated with poor prognosis in ovarian cancer (Curiel et al., 2004) and gastrointestinal sarcoma (Balachandran et al., 2011), but they constitute a predictor of favorable clinical outcome in head and neck (Badoual et al., 2006), colorectal cancers (Salama et al., 2009), and Hodgkin lymphoma (Carreras et al., 2006). What emerges from numerous studies is that, even if the density of infiltrating adaptive immune cells decreases upon tumor spreading (Mlecnik et al., 2011), their main impact is on survival of the patients. It thus raises the hypothesis that cancer therapies with long-term beneficial effects may have limited impact on local disease but should activate a relevant adaptive immune reaction that will result in control of potential metastatic spreading and establish an homeostasis which allows patients to live with a controlled disease.

Pioneering work by Laurence Zitvogel and Guido Kroemer, in mouse models, revealed that chemotherapy could retard the growth of tumors growing on immunocompetent but had no effect on tumors established on immunodeficient mice (Zitvogel et al., 2008, 2011; Galluzzi et al., 2011). Based on these results, the concept of immunogenic chemotherapy was launched hypothesizing that a drug is curative if it provokes an immunogenic death of the malignant cells, thereby inducing an adaptive immune response which clears, or maintains dormant, escaping tumor cells. The molecular mechanisms of the immunogenic cell death have been deciphered. The exposition of calreticulin on the surface of the dying tumor cells increases their uptake by DC. DC are also stimulated by HMGB1 and ATP released from dying tumor cells, which act on TLR4 (Apetoh et al., 2007) and P2RX7 (Ghiringhelli et al., 2009) among other receptors, respectively favor processing of tumor antigens and Tc1 polarization of CD8+ T lymphocytes (Ghiringhelli et al., 2009) allowing for the subsequent activation of an adaptive immune reaction. Indeed in retrospective studies, polymorphisms of TLR4 and P2RX7 were associated with survival in chemotherapy treated patients (Apetoh et al., 2007; Ghiringhelli et al., 2009). Strikingly, a recent study of DTIC treated metastatic melanoma showed that survival was indeed correlated, among other factors, with $\mathrm{T}$ cell infiltration in metastases (Nardin et al., 2011). In human, high T cell infiltration of hepatic metastases of colorectal cancer was a predictor of patient's response to chemotherapy (Halama et al., 2011). Thus, although drug-induced tumor shrinkage is independent of the immune reaction, patient survival may be the consequence of the induction/increase of a sustained immune reaction. In line with these results, clinical efficacy of radiotherapy also required CD8+ T cells, in preclinical models (Lee et al., 2009).

The analysis of the effects of immunotherapies leads to the same conclusion. In mouse models, it was demonstrated that although the clearance of an autologous CD20 positive lymphoma or an HER2 positive carcinoma by anti-CD20 (Abès et al., 2010) and anti-HER2 (Park et al., 2010) monoclonal antibodies respectively, requires NK cells, an equilibrium phase is established that involves an antigenspecific T cell response (Abès et al., 2010; Park et al., 2010; Abès and Teillaud, 2011; Stagg et al., 2011). A second graft of the tumor is rejected in an antigen-specific manner, without a second antibody challenge. If CD4 cells are depleted during the treatment with the therapeutic monoclonal antibody (the induction phase) such memory is not induced, and if CD8 cells are removed prior to the second graft (the maintenance phase), it is not rejected (Abès et al., 2010). In human, administration of anti-HER2/neu monoclonal antibodies also induced endogenous anti-HER2/neu humoral and cellular immune responses (Taylor et al., 2007). Thus, the long-term effects of therapeutic anti-tumor antibodies are also mediated by an adaptive $\mathrm{T}$ cell response (Abès et al., 2010; Park et al., 2010; Stagg et al., 2011).
The case of ipilimumab is even more striking. Metastatic melanoma sites either shrink, or are not modified in size or grow during antibody treatment, or even new sites appear. The only significant effect is an increase of patients overall survival, an excellent predictor of this effect being again the infiltration of metastatic sites by CD8 T cells. Treatment with anti-PD1 antibodies follows the same rules (Nomi et al., 2007). Strikingly, treatment with anti-angiogenic agents reveals a similar phenomenon. A recently published clinical trial where patients with metastatic renal cancer were treated with sunitinib (an inhibitor of VEGF receptor signaling) with or without bevacizumab (an anti VEGF-A antibody) revealed that some of them had a decrease in regulatory $\mathrm{T}$ cells. The patients with decreased Treg had a longer survival than the group of patients on which Treg decrease was not induced (Adotevi et al., 2010). Interestingly, the decrease of Treg did not correlate with clinical response assessed by Recist criteria but only with overall survival. In patients treated with sunitinib in a neoadjuvant setting, i.e., before surgery, a decrease in intra-tumoral regulatory $\mathrm{T}$ cells was detected. Finally, it is striking that in patients presenting with metastatic prostate cancer treated with therapeutic vaccines, there was no effect of disease progression but only on overall survival (Kantoff et al., 2010; Beer et al., 2011; Gulley and Drake, 2011). It is tempting to speculate that the effect on overall (but not progression-free survival is the consequence of the induction of an adaptive immune response to the vaccine and putatively to the tumor.

From these examples, it clearly results that these are two important steps should be attained by anti-cancer therapies: the first one is to reduce the tumor burden by surgery, radiotherapy, chemotherapy, or anti-tumor antibodies. If some tumor cells escape these treatments, the cure of cancer, or at least its maintenance in an equilibrium stage, is the result of the second step, i.e., the induction of an adaptive $\mathrm{T}$ cell response which may be efficiently sustained by immunomodulatory agents.

To reach long-term survival and therefore clinical cure of cancerous patients, innovative treatments regimen should take into account these two steps. 


\section{REFERENCES}

Abès, R., Gélizé, E., Fridman, W. H., and Teillaud, J. L. (2010). Long-lasting antitumor protection by antiCD20 antibody through cellular immune response. Blood 116, 926-934.

Abès, R., and Teillaud, J. L. (2011). Modulation of tumor immunity by therapeutic monoclonal antibodies. Cancer Metastasis Rev. 30, 111-124.

Adotevi, O., Pere, H., Ravel, P., Haicheur, N., Badoual, C., Merillon, N., Medioni, J., Peyrard, S., Roncelin, S., Verkarre, V., Mejean, A., Fridman, W. H., Oudard, S., and Tartour, E. (2010). A decrease of regulatory T cells correlates with overall survival after sunitinib-based antiangiogenic therapy in metastatic renal cancer patients. J. Immunother. 33, 991-998.

Apetoh, L., Ghiringhelli, F., Tesniere, A., Obeid, M., Ortiz, C., Criollo, A., Mignot, G., Maiuri, M. C., Ullrich, E., Saulnier, P., Yang, H., Amigorena, S., Ryffel, B., Barrat, F. J., Saftig, P., Levi, F., Lidereau, R., Nogues, C., Mira, J. P., Chompret, A., Joulin, V., Clavel-Chapelon, F., Bourhis, J., André, F., Delaloge, S., Tursz, T., Kroemer, G., and Zitvogel, L. (2007). Toll-like receptor 4-dependent contribution of the immune system to anticancer chemotherapy and radiotherapy. Nat. Med. 13, 1050-1059.

Ashfaq, K., Yahaya, I., Hyde, C., Andronis, L., Barton, P., Bayliss, S., and Chen, Y. F. (2010). Clinical effectiveness and cost-effectiveness of stem cell transplantation in the management of acute leukaemia: a systematic review. Health Technol. Assess. (Rockv.) 14, iii-iv, ix-xi, $1-141$.

Badoual, C., Hans, S., Rodriguez, J., Peyrard, S., Klein, C., Agueznay Nel, H., Mosseri, V., Laccourreye, O., Bruneval, P., Fridman, W. H., Brasnu, D. F., and Tartour, E. (2006). Prognostic value of tumor-infiltrating CD4+ T-cell subpopulations in head and neck cancers. Clin. Cancer Res. 12, 465-472.

Balachandran, V. P., Cavnar, M. J., Zeng, S., Bamboat, Z. M., Ocuin, L. M., Obaid, H., Sorenson, E. C., Popow, R., Ariyan, C., Rossi, F., Besmer, P., Guo, T., Antonescu, C. R., Taguchi, T., Yuan, J., Wolchok, J. D., Allison, J. P., and Dematteo, R. P. (2011). Imatinib potentiates antitumor $\mathrm{T}$ cell responses in gastrointestinal stromal tumor through the inhibition of Ido. Nat. Med. 17, 1094-1100.

Beer, T. M., Bernstein, G. T., Corman, J. M., Glode, L. M., Hall, S. J., Poll, W. L., Schellhammer, P. F., Jones, L. A., Xu, Y., Kylstra, J. W., and Frohlich, M. W. (2011). Randomized trial of autologous cellular immunotherapy with sipuleucel- $\mathrm{T}$ in androgen-dependent prostate cancer. Clin. Cancer Res. 17, 4558-4567.

Carreras, J., Lopez-Guillermo, A., Fox, B. C., Colomo, L., Martinez, A., Roncador, G., Montserrat, E., Campo, E., and Banham, A. H. (2006). High numbers of tumor-infiltrating FOXP3-positive regulatory T cells are associated with improved overall survival in follicular lymphoma. Blood 108, 2957-2964.

Carter, P. (2006). Potent antibody therapeutics by design. Nat. Rev. Immunol. 6, 343-357.

Clynes, R., Takechi, Y., Moroi, Y., Houghton, A., and Ravetch, J.V. (1998). Fc receptors are required in passive and active immunity to melanoma. Proc. Natl. Acad. Sci. U.S.A. 95, 652-656.

Curiel, T. J., Coukos, G., Zou, L., Alvarez, X., Cheng, P., Mottram, P., Evdemon-Hogan, M., Conejo-Garcia, J. R., Zhang, L., Burow, M., Zhu, Y., Wei, S., Kryczek, I., Daniel, B., Gordon, A., Myers, L., Lackner, A., Disis, M. L., Knutson, K. L., Chen, L., and Zou, W. (2004). Specific recruitment of regulatory $\mathrm{T}$ cells in ovarian carcinoma fosters immune privilege and predicts reduced survival. Nat. Med. 10, 942-949.

Disis, M. L. (2010). Immune regulation of cancer. J. Clin. Oncol. 28, 4531-4538.

Finn, O. J. (2008). Cancer immunology. N. Engl. J. Med. 358, 2704-2715.

Fridman, W. H., Galon, J., Dieu-Nosjean, M. C., Cremer, I., Fisson, S., Damotte, D., Pagès, F., Tartour, E., and Sautès-Fridman, C. (2011a). Immune infiltration in human cancer: prognostic significance and disease control. Curr. Top. Microbiol. Immunol. 344, 1-24.

Fridman, W. H., Mlecnik, B., Bindea, G., Pagès, F., and Galon, J. (2011b). Immunosurveillance in human non-viral cancers. Curr. Opin. Immunol. 23, 272-278.

Galluzzi, L., and Kroemer, G. (2011). Trial watch. Monoclonal antibodies in cancer therapy. Front. Oncol. 1.5.

Galluzzi, L., Vacchelli, E., Albert Matthew, L., Fridman, W. H., Galon, J., Sautès-Fridman, C., Tartour, E. Zucman-Rossi, J., Zitvogel, L., and Kroemer, G. (in press). Trial Watch, monoclonal antibodies in cancer therapy. Oncoimmunology.

Galon, J., Costes, A., Sanchez-Cabo, F., Kirilovsky, A. Mlecnik, B., Lagorce-Pagès, C., Tosolini, M., Camus, M., Berger, A., Wind, P., Zinzindohoué, F., Bruneval, P., Cugnenc, P. H., Trajanoski, Z., Fridman, W. H., and Pagès, F. (2006). Type, density, and location of immune cells within human colorectal tumors predict clinical outcome. Science 313, 1960-1964.

Ghiringhelli, F., Apetoh, L., Tesniere, A., Aymeric, L., Ma, Y., Ortiz, C., Vermaelen, K., Panaretakis, T., Mignot, G., Ullrich, E., Perfettini, J. L., Schlemmer, F., Tasdemir, E., Uhl, M., Génin, P., Civas, A., Ryffel, B., Kanellopoulos, J., Tschopp, J., André, F., Lidereau, R., McLaughlin, N. M., Haynes, N. M., Smyth, M. J., Kroemer, G., and Zitvogel, L. (2009). Activation of the NLRP3 inflammasome in dendritic cells induces IL-1beta-dependent adaptive immunity against tumors. Nat. Med. 15, 1170-1178.

Gulley, J. L., and Drake, C. G. (2011). Immunotherapy for prostate cancer: recent advances, lessons learned, and areas for further research. Clin. Cancer Res. 17, 3884-3891.

Halama, N., Michel, S., Kloor, M., Zoernig, I., Benner, A., Spille, A., Pommerencke, T., von Knebel, D. M., Folprecht, G., Luber, B., Feyen, N., Martens, U. M., Beckhove, P., Gnjatic, S., Schirmacher, P., Herpel, E., Weitz, J., Grabe, N., and Jaeger, D. (2011). Localization and density of immune cells in the invasive margin of human colorectal cancer liver metastases are prognostic for response to chemotherapy. Cancer Res. 71, 5670-5677.

Hodi, F. S., O’Day, S. J., McDermott, D. F., Weber, R. W., Sosman, J. A., Haanen, J. B., Gonzalez, R., Robert, C., Schadendorf, D., Hassel, J. C., Akerley, W., van den Eertwegh, A. J., Lutzky, J., Lorigan, P., Vaubel, J. M., Linette, G. P., Hogg, D., Ottensmeier, C. H., Lebbé, C., Peschel, C., Quirt, I., Clark, J. I., Wolchok, J. D., Weber, J. S., Tian, J., Yellin, M. J., Nichol, G. M., Hoos, A., and Urba, W. J. (2010). Improved survival with ipilimumab in patients with metastatic melanoma. N. Engl. J. Med. 363, 711-723.

Kantoff, P. W., Schuetz, T. J., Blumenstein, B. A., Glode, L. M., Bilhartz, D. L., Wyand, M., Manson, K., Panicali, D. L., Laus, R., Schlom, J., Dahut, W. L., Arlen, P. M., Gulley, J. L., and Godfrey, W. R. (2010). Overall survival analysis of a phase II randomized controlled trial of a Poxviral-based PSA-targeted immunotherapy in metastatic castration-resistant prostate cancer. J. Clin. Oncol. 28, 1099-1105.
Kline, J., and Gajewski, T. F. (2010). Clinical development of mAbs to block the PD1 pathway as an immunotherapy for cancer. Curr. Opin. Investig. Drugs 11, 1354-1359.

Lee, Y., Auh, S. L., Wang, Y., Burnette, B., Wang, Y., Meng, Y., Beckett, M., Sharma, R., Chin. R., Tu, T., Weichselbaum, R. R., and Fu, Y.X. (2009). Therapeutic effects of ablative radiation on local tumor require CD8+ T cells: changing strategies for cancer treatment. Blood 114, 589-589.

Mlecnik, B., Tosolini, M., Kirilovsky, A., Berger, A., Bindea, G., Meatchi, T., Bruneval, P., Trajanoski, Z., Fridman, W.H., Pagès, F., and Galon, J. (2011). Histopathologicbased prognostic factors of colorectal cancers are associated with the state of the local immune reaction. J. Clin. Oncol. 29, 610-618.

Nardin, A., Wong, W. C., Tow, C., Molina, T. J., Tissier, F., Audebourg, A., Garcette, M., Caignard, A., Avril, M. F., Abastado, J. P., and Prévost-Blondel, A. (2011). Dacarbazine promotes stromal remodeling and lymphocyte infiltration in cutaneous melanoma lesions. J. Invest. Dermatol. 131, 1896-1905.

Nomi, T., Sho, M., Akahori, T., Hamada, K., Kubo, A., Kanehiro, H., Nakamura, S., Enomoto, K., Yagita, H., Azuma, M., and Nakajima, Y. (2007). Clinical significance and therapeutic potential of the programmed death-1 ligand/programmed death-1 pathway in human pancreatic cancer. Clin. Cancer Res. 13, 2151-2157.

Pagès, F., Galon, J., Dieu-Nosjean, M. C., Tartour, E., Sautès-Fridman, C., and Fridman, W. H. (2010). Immune infiltration in human tumors: a prognostic factor that should not be ignored. Oncogene 29, 1093-1102.

Park, S., Jiang, Z., Mortenson, E. D., Deng, L., RadkevichBrown, O., Yang, X., Sattar, H., Wang, Y., Brown, N K., Greene, M., Liu, Y., Tang, J., Wang, S., and Fu, Y. X. (2010). The therapeutic effect of anti-HER2/neu antibody depends on both innate and adaptive immunity. Cancer Cell 18, 160-170.

Rosenberg, S. A., Lotze, M. T., Muul, L. M., Chang, A. E., Avis, F. P., Leitman, S., Linehan, W. M., Robertson, C. N., Lee, R. E., Rubin, J. T., et al. (1987). A progress report on the treatment of 157 patients with advanced cancer using lymphokine-activated killer cells and interleukin-2 or high-dose interleukin-2 alone. $N$. Engl. J. Med. 316, 889-897.

Rosenberg, S. A., Yang, J. C., Sherry, R. M., Kammula, U. S., Hughes, M. S., Phan, G. Q., Citrin, D. E., Restifo, N. P., Robbins, P. F., Wunderlich, J. R., Morton, K. E., Laurencot, C. M., Steinberg, S. M., White, D. E., and Dudley, M. E. (2011). Durable complete responses in heavily pretreated patients with metastatic melanoma using T-cell transfer immunotherapy. Clin. Cancer Res. 17, 4550-4557.

Rosenblatt, J., Glotzbecker, B., Mills, H., Vasir, B., Tzachanis, D., Levine, J. D., Joyce, R. M., Wellenstein, K., Keefe, W., Schickler, M., Rotem-Yehudar, R., Kufe, D., and Avigan, D. (2011). PD-1 blockade by CT-011, anti-PD-1 antibody, enhances ex vivo T-cell responses to autologous dendritic cell/myeloma fusion vaccine. J. Immunother. 34, 409-418.

Salama, P., Phillips, M., Grieu, F., Morris, M., Zeps, N., Joseph, D., Platell, C., and Iacopetta, B. (2009). Tumorinfiltrating FOXP3+ T regulatory cells show strong prognostic significance in colorectal cancer. J. Clin. Oncol. 27, 186-192.

Stagg, J., Loi, S., Divisekera, U., Ngiow, S. F., Duret, H., Yagita, H., Teng, M. W., and Smyth, M. J. (2011). Anti-ErbB-2 mAb therapy requires type I and II 
interferons and synergizes with anti-PD-1 or antiCD137 mAb therapy. Proc. Natl. Acad. Sci. U.S.A. 108, 7142-7147.

Tartour, E., Blay, J. Y., Dorval, T., Escudier, B., Mosseri, V., Douillard, J. Y., Deneux, L., Gorin, I., Negrier, S., Mathiot, C., Pouillart, P., and Fridman, W. H. (1996). Predictors of clinical response to interleukin2-based immunotherapy in melanoma patients: a French multiinstitutional study. J. Clin. Oncol. 14, 1697-1703.

Tartour, E., Pere, H., Maillere, B., Terme, M., Merillon, N., Taieb, J., Sandoval, F., Quintin-Colonna, F., Lacerda, K., Karadimou, A., Badoual, C., Tedgui, A., Fridman, W.H., and Oudard, S. (2011). Angiogenesis and immunity: a bidirectional link potentially relevant for the monitoring of antiangiogenic therapy and the development of novel therapeutic combination with immunotherapy. Cancer Metastasis Rev. 30, 83-95.

Taylor, C., Hershman, D., Shah, N., Suciu-Foca, N., Petrylak, D. P., Taub, R., Vahdat, L., Cheng, B., Pegram, M., Knutson, K. L., and Clynes, R. (2007). Augmented HER-2 specific immunity during treatment with trastuzumab and chemotherapy. Clin. Cancer Res. 13, 5133-5143.
Tosolini, M., Kirilovsky, A., Mlecnik, B., Fredriksen, T., Mauger, S., Bindea, G., Berger, A., Bruneval, P., Fridman, W. H., Pagès, F., and Galon, J. (2011). Clinical impact of different classes of infiltrating $\mathrm{T}$ cytotoxic and helper cells (Th1, th2, treg, th17) in patients with colorectal cancer. Cancer Res. 71, 1263-1271.

Waldmann, T. A. (2006). Effective cancer therapy through immunomodulation. Annu. Rev. Med. 57, 65-81.

Yang, J. C., Haworth, L., Sherry, R. M., Hwu, P., Schwartzentruber, D. J., Topalian, S. L., Steinberg, S. M., Chen, H. X., and Rosenberg, S. A. (2003). A randomized trial of bevacizumab, an anti-vascular endothelial growth factor antibody, for metastatic renal cancer. N. Engl. J. Med. 349, 427-434.

Yuan, J., Adamow, M., Ginsberg, B. A., Rasalan, T. S., Ritter, E., Gallardo, H. F., Xu, Y., Pogoriler, E., Terzulli, S. L., Kuk, D., Panageas, K. S., Ritter, G., Sznol, M., Halaban, R., Jungbluth, A. A., Allison, J. P., Old, L. J., Wolchok, J. D., and Gnjatic, S. (2011). Integrated NY-ESO-1 antibody and CD8+ T-cell responses correlate with clinical benefit in advanced melanoma patients treated with ipilimumab. Proc. Natl. Acad. Sci. U.S.A. 108, 16723-16728.
Zitvogel, L., Apetoh, L., Ghiringhelli, F., and Kroemer, G. (2008). Immunological aspects of cancer chemotherapy. Nat. Rev. Immunol. 8, 59-73.

Zitvogel, L., Kepp, O., and Kroemer, G. (2011). Immune parameters affecting the efficacy of chemotherapeutic regimens. Nat. Rev. Clin. Oncol. $8,151-160$.

Received: 14 October 2011; accepted: 09 November 2011; published online: 01 December 2011.

Citation: Fridman WH, Teillaud J-L, Sautès-Fridman C, Pagès F, Galon J, Zucman-Rossi J, Tartour E, Zitvogel $L$ and Kroemer $G$ (2011) The ultimate goal of curative anti-cancer therapies: inducing an adaptive anti-tumor immune response. Front. Immun. 2:66. doi: 10.3389/ fimmu.2011.00066

This article was submitted to Frontiers in Tumor Immunity, a specialty of Frontiers in Immunology.

Copyright () 2011 Fridman, Teillaud, Sautès-Fridman, Pagès, Galon, Zucman-Rossi, Tartour, Zitvogel and Kroemer. This is an open-access article distributed under the terms of the Creative Commons Attribution Non Commercial License, which permits non-commercial use, distribution, and reproduction in other forums, provided the original authors and source are credited. 